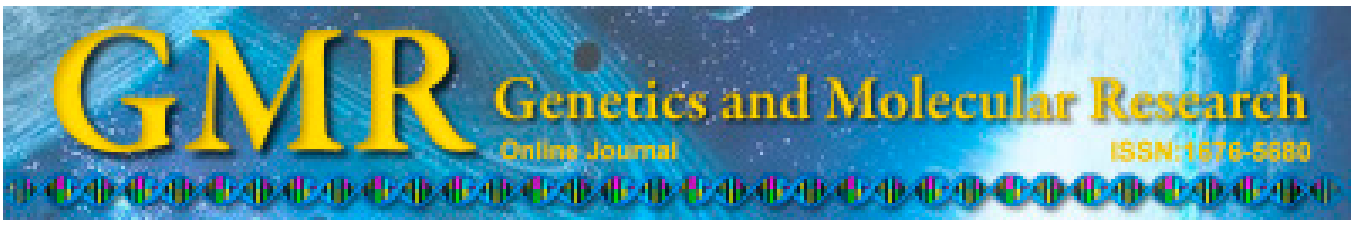

\title{
CYP19 gene polymorphisms and the susceptibility to breast cancer in Xinjiang Uigur women
}

\author{
L. Yang, X.Y. Wang, Y.T. Li, H.L. Wang, T. Wu, B. Wang, Q. Zhao, \\ D. Jinsihan and L.P. Zhu
}

The Department of Mammary Surgery in the Cancer Hospital Affiliated with Xinjiang Medical University, Urumqi,

The Xinjiang Uygur Autonomous Region, China

*These authors contributed equally to this study.

Corresponding author: L.P. Zhu

E-mail: zhuliping_1p@163.com

Genet. Mol. Res. 14 (3): 8473-8482 (2015)

Received December 4, 2014

Accepted April 27, 2015

Published July 28, 2015

DOI http://dx.doi.org/10.4238/2015.July.28.15

\begin{abstract}
In this study, the relationship between CYP19 gene polymorphisms and breast cancer in Xinjiang Uigur women was investigated. A case-control study was designed to compare 112 Uigur breast cancer patients with 139 Uigur healthy controls. Individuals were genotyped for the CYP19 rs10046 polymorphism using polymerase chain reaction restriction fragment length polymorphism (PCR-RFLP). Accordingly, the relationship between the rs10046 polymorphism and the susceptibility of Xinjiang Uigur women to breast cancer was analyzed. Given that the allele at the rs 10046 site varies between $C$ and $\mathrm{T}$ within the CYP19 gene, the frequency distribution of the $\mathrm{C}$ and $\mathrm{T}$ allele in breast cancer subjects were 48.2 and $51.8 \%$ respectively, and 47.5 and $52.5 \%$ in control cases. Moreover, the frequency distribution of the TC, CC, and TT genotype were $26.8,42.9$, and $30.4 \%$ in breast
\end{abstract}


cancer cases, but 18.0, 59.0, and 23.0\% in control cases $(\mathrm{P}<0.05)$. Risk factors within the Uigur population for breast cancer included an age $\geq 50$ years old, a BMI $\geq 25 \mathrm{~kg} / \mathrm{m}^{2}$, and a parity $\geq 2$. Conversely, an abortion and the CYP19 rs10046 TC genotype were protective factors. Menopause was another independent risk factor for breast cancer in Uigur women after the correction for age, BMI, age at first parity, pregnancy, and breastfeeding. In conclusion, breast cancer in Xinjiang Uigur women is closely connected with the age, BMI, parity, abortion, and CYP19 rs 10046 polymorphisms. The TC genotype and an abortion can reduce the risk of the breast cancer disease in Uigur women.

Key words: Breast cancer; CYP19 gene; Uigur; Gene polymorphisms

\section{INTRODUCTION}

Breast cancer is the most common malignant tumor in women, and hormone balance plays a key role in its development. Aromatase, which is encoded by the aromatase gene, CYP19, is a key enzyme in estrogen metabolism. CYP19 gene polymorphisms have been known to cause changes in enzyme activity and have influenced the synthesis of estrogen. This suggests a possible role of CYP19 gene polymorphisms in breast cancer initiation and progression. Our study selected breast cancer patients and healthy controls in Uigur women in Xinjiang and attempted to determine the association between CYP19 rs10046 site polymorphism and its relation to susceptibility to breast cancer.

\section{MATERIAL AND METHODS}

\section{Patients}

One hundred and twelve Uigur women with newly diagnosed breast cancer and 139 healthy control cases visiting the Cancer Hospital Affiliated to Xinjiang Medical University from October 2010 to July 2012 were used for this study. The youngest breast cancer patients were 22 years old, and the oldest was 71 , the average age was $44.45 \pm 9.22$ years old. With respect to control cases, the youngest control cases were 25 years old, and the oldest were 65 , with the mean age being $45.30 \pm 9.60$ years old. The result had no significant difference $(\mathrm{P}>0.05)$. The incidence of invasive ductal carcinoma in the patient group was 82 cases $(73 \%)$. The 139 control patients were Uigur women that went through a health medical examination in the three-A General Hospital, and were all community residents in Urumchi. All general information for both groups was obtained at the same time, including the postoperative pathology, menopause, menstrual history, malignant tumor family history, pregnancy histories, and lactation history.

\section{Selection}

\section{Inclusion criteria of case group}

The following are the inclusion criteria for the breast cancer patients group: 1) the 
primary breast cancer in Uigur women got histodiagnosis, 2) they had no endocrine, radiation, and/or chemical therapy prior to admission, 3) they had no other malignant tumor history, and no breast cancer metastasis, advanced breast cancer, or mental disease, 4) they provided informed consent, and signed the medical informed consent document, and 5) it was on the Ethics Committee approval.

\section{Exclusion criteria of case group}

The following are the exclusion criteria for the breast cancer patient group: 1) they had received hormone therapy prior to admission, 2) they had severe heart, lung, liver, kidney, and/or other organ dysfunction, and 3) they had lived in Xinjiang for less than 10 years.

\section{Inclusion criteria of control group}

The following are the inclusion criteria for the control group: 1) they were Uigur women that had a healthy medical examination, 2) they were \pm 5 years matched to the case group, and 3) they were under the Ethics Committee approval, provided informed consent, and signed the medical informed consent document.

\section{Exclusion criteria of control group}

The following are the exclusion criteria for the control group: 1) they received hormone therapy, 2) they possessed heart, lung, liver, kidney, and/or other organ dysfunction previously, and 3) they had lived in Xinjiang less than 10 years, and 4) they were at gestation or breastfeeding period.

\section{Detection in the laboratory}

\section{Materials and Reagents}

Whole Blood Gene Extraction Kit was purchased from TIANGEN Biotech Co., Ltd (Beijing, China). The primers were synthesized by Shanghai Biological Technology Service Company. The restriction enzyme $S d u \mathrm{I}(\mathrm{Bsp} 1286)(10 \mathrm{U} / \mu \mathrm{L})$ was purchased from MBI Fermentas Co. (Canada).

\section{Methods}

Two milliliters of blood was collected in an EDTA vacutainer from patients as well as controls. Genomic DNA was extracted using a Whole Blood Gene Extraction Kit following the manufacturer protocol and stored at $-20^{\circ} \mathrm{C}$. Genotyping for the CYP19 rs10046 (CYP19 E10 c. +19C>T; located in exon 10, 19 bp downstream from the amber stop codon) polymorphisms was performed using polymerase chain reaction restriction fragment length polymorphism (PCR-RFLP). Alternatively, genotyping of the SNP rs10046 was performed by two separate allele-specific conventional PCRs with the following primers: forward, 5'-CTGGAACACTAGAGAAGGCTGGTCAGTGC-3'; and reverse, 
5'-GTTCTCTGGTGTGAACAGGAGATGAC-3'. The PCRs were initiated with denaturation at $95^{\circ} \mathrm{C}$ for $5 \mathrm{~min}$, denaturation at $95^{\circ} \mathrm{C}$ for $30 \mathrm{~s}$, followed by renaturation at $63^{\circ} \mathrm{C}$ for $30 \mathrm{~s}$, elongation at $72^{\circ} \mathrm{C}$ for $30 \mathrm{~s}$ and elongation at $72^{\circ} \mathrm{C}$ for $5 \mathrm{~min}(40$ cycles). PCR products were separated by electrophoresis on a $2 \%$ agarose gel under $110 \mathrm{~V}$ for $30 \mathrm{~min}$, and the objective band was $202 \mathrm{bp}$. The PCR products were digested by the restriction enzyme $S d u \mathrm{I}$ ( $B s p 1286)$ at $37^{\circ} \mathrm{C}$ overnight.

The arginine allele (CC) was identified by the presence of 172- and 30-bp fragments. Alternatively, the tryptophan allele (TT) was identified by 202-bp fragments, while the TC allele was identified with the 202-, 172-, and 30-bp fragments. Some CYP19 rs10046 PCR products were selected to sequence.

\section{Statistical analysis}

Data were analyzed using SPSS16.0, and the genotype was measured according to Hardy-Weinberg $(\mathrm{H}-\mathrm{W})$. Allele frequency differences between the groups were examined by the $\chi^{2}$ test. Breast cancer disease factors were analyzed by univariate and multivariate logistic regression analysis, and then by calculating the odds ratio (OR) and $95 \%$ confidence interval (CI). The variation allele frequency of the CYP19 rs 10046 site was analyzed by the $\chi^{2}$ test (size of test $\alpha=0.05$ ). A P value of $<0.05$ was considered to be significant.

\section{RESULTS}

\section{Detection of genotype DNA}

The genomic DNA was detected using UV spectrophotometry, and the average concentration of DNA for the 251 patients was $566.20 \mathrm{ng} / \mu \mathrm{L}$.

\section{PCR of CYP19}

The PCR products of the CYP19 fragment was $202 \mathrm{bp}$, which was located between the third band $300 \mathrm{bp}$ and the forth band 200 (closer to the $200 \mathrm{bp}$ band). If there was no band, we recorded the case and its number, and then repeated it one more time. Genomic DNA was extracted again when it was necessary (Figure 1).

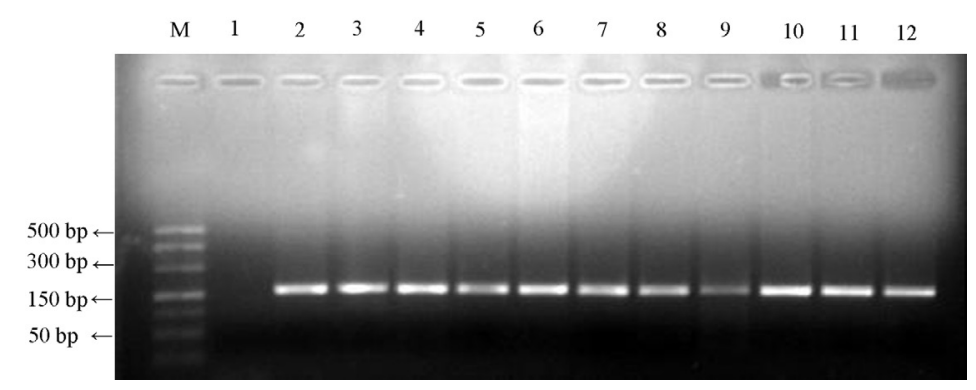

Figure 1. CYP19 gene PCR products separated by gel electrophoresis. Lanes on the agarose gel are denoted: lane $M=$ marker, and lanes $1-12=$ PCR products. 


\section{Restriction enzyme $S d u I$ (Bsp1286) digestion of CYP19}

The arginine allele (CC) was identified by the presence of 172 and $30 \mathrm{bp}$ fragments. Alternatively, the tryptophan allele (TT) was identified by 202-bp fragments, and the TC allele was identified by 202-, 172- and 30-bp fragments (Figure 2).

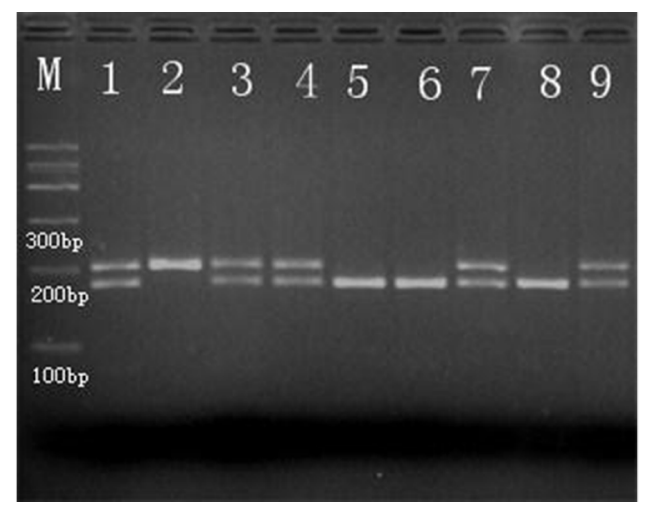

Figure 2. Restriction enzyme $S d u \mathrm{I}(B s p 1286)$ digestion of $C Y P 19$ gene mapping. Lanes on the agarose gel are denoted: lane $M=$ marker, lanes $1-9=$ mutant TT, lanes $1,3,4,7$, and $9=$ heterozygote TC, and lanes 5, 6, and 8 = wild-type CC.

\section{Sequencing of PCR products}

The CYP19 rs10046 three genotype PCR products were randomly selected to sequence. The base changes in the sequence results were consistent with the results of enzyme digestion (Figure 3A-C).

\section{H-W balanced detection}

H-W balance analysis was made using the SPSS16.0 software, and in the breast cancer case group $\chi^{2}=2.464(\mathrm{P}>0.05$; Table 1$)$, and in the control group $\chi^{2}=2.092(\mathrm{P}>0.05$; Table 2). The genotype of the breast cancer case group and control group were in accordance with H-W. It was shown that the expected and actual values tallied well for both genotype and allele. The randomness of samples was good, and they belonged to the same Mendelian population. The patients in the cases group could be said to represent the native breast cancer patients.

\section{Comparison of the breast cancer-related risk factors}

After stratified analysis of each factor, it was revealed that age was a risk factor in breast cancer for Xinjiang Uigur women. Compared with $\leq 35$ year old women, the number of breast cancer cases for women above 50 years old was higher $(\mathrm{OR}=6.618,95 \% \mathrm{CI}=2.645$ 16.558). Similarly, the breast cancer risk of women in menopause was 5.864-fold higher than in non-menopause Uigur women $(95 \% \mathrm{CI}=2.75-12.505)$. After stratified analysis of menarche age, it was not shown to have a relationship with the incidence of breast cancer in this population. The breast cancer risk was, however, found to be higher as the parity times increased. 
For instance, the breast cancer risk of parity two times was 1.956-fold that of the parity one time in Uigur women $(95 \% \mathrm{CI}=1.004-3.81)$, while the three times was 4.644 fold that of 1 time $(95 \% \mathrm{CI}=2.149-10.037)$. Abortion was a protective factor against breast cancer for Uigur women $(\mathrm{OR}=0.469,95 \% \mathrm{CI}=0.282-0.78)$. There was no relationship between the childbearing age and breastfeeding time with breast cancer (Table 3 ).
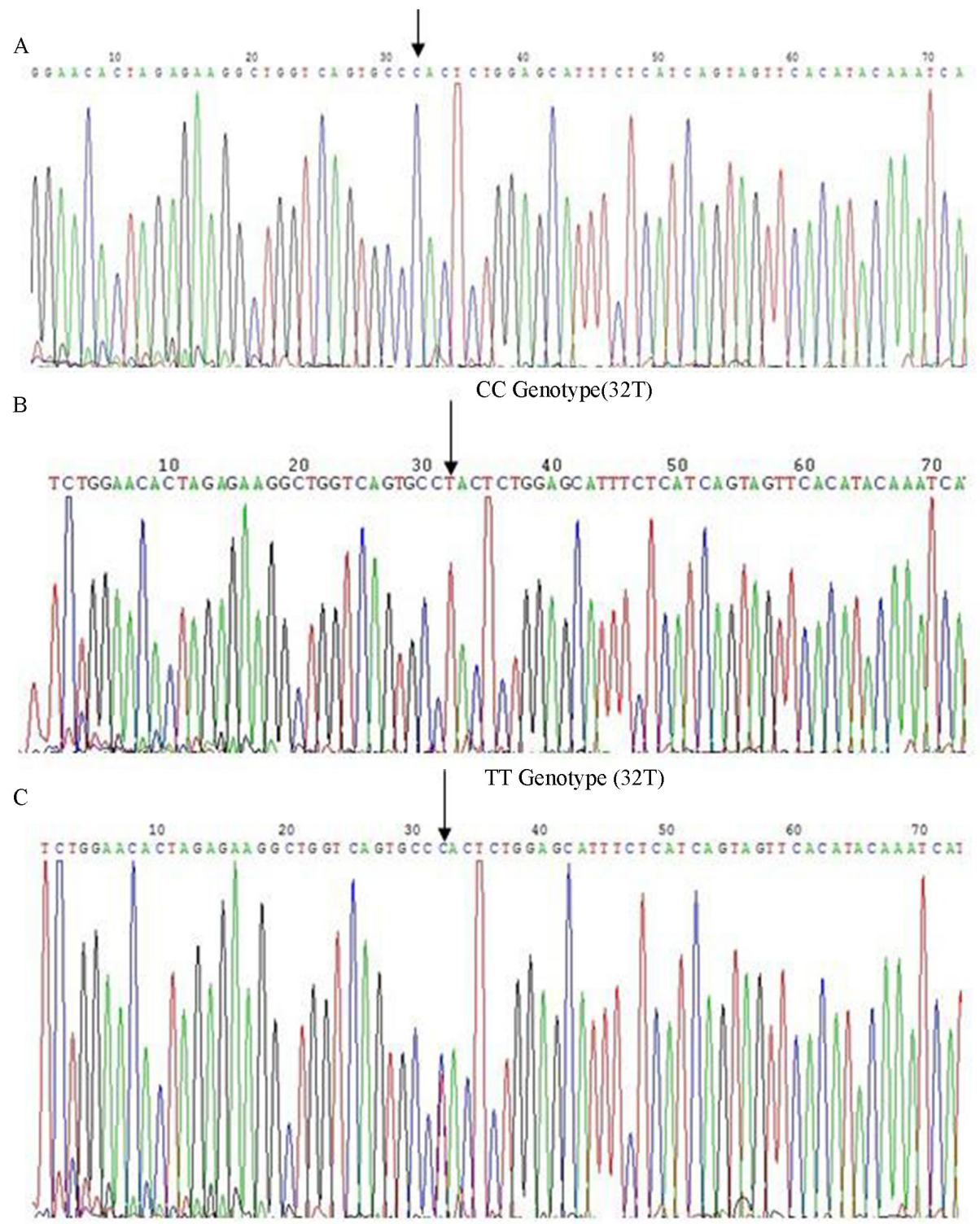

TC Genotype (32C/T)

Figure 3. CYP19 PCR amplification. 
Table 1. Hardy-Weinberg balanced detection in the breast cancer group.

\begin{tabular}{lccc}
\hline Genotype & Practical frequency (\%) & Theoretical frequency $(\%)$ & $\chi^{2}$ \\
\hline CC & $301(26.8)$ & $20(17.9)$ & \\
TC & $48(42.9)$ & $52(46.4)$ & 2.46 \\
TT & $34(30.4)$ & $40(35.8)$ & 4 \\
\hline
\end{tabular}

Table 2. Hardy-Weinberg balanced detection in the control group.

\begin{tabular}{lccr}
\hline Genotype & Practical Frequency (\%) & Theoretical frequency $(\%)$ & $\chi^{2}$ \\
\hline CC & $25(18.0)$ & $30(21.6)$ & \\
TC & $82(59)$ & $70(50.4)$ & 2.092 \\
TT & $32(27.0)$ & $39(28.1)$ & 0.351 \\
\hline
\end{tabular}

Table 3. A comparison of breast cancer risk factors between the case and control groups.

\begin{tabular}{|c|c|c|c|c|c|}
\hline \multirow{2}{*}{$\frac{\text { Variable }}{\text { Age (year }}$} & \multirow[t]{2}{*}{ Cases $(\%)$} & \multirow[t]{2}{*}{ Control (\%) } & \multirow[t]{2}{*}{ OR } & \multicolumn{2}{|c|}{$95 \% \mathrm{CI}$} \\
\hline & & & & & \\
\hline$\leq 35$ & $15(13.39)$ & $39(28.06)$ & 1 & & \\
\hline $36-49$ & $69(61.61)$ & $89(64.03)$ & 1.831 & 0.936 & 3.579 \\
\hline$\geq 50$ & $28(25.00)$ & $11(7.91)$ & 6.618 & 2.645 & 16.558 \\
\hline \multicolumn{6}{|c|}{ Menarche age } \\
\hline$\geq 12$ & $36(32.14)$ & $51(36.69)$ & 1 & & \\
\hline $13-16$ & $63(56.25)$ & $75(53.96)$ & 1.19 & 0.629 & 2.047 \\
\hline$\leq 17$ & $13(11.61)$ & $13(9.35)$ & 1.417 & 0.588 & 3.413 \\
\hline \multicolumn{6}{|c|}{ Menopause } \\
\hline No & $77(68.75)$ & $129(92.81)$ & 1 & & \\
\hline Yes & $35(31.25)$ & $10(7.19)$ & 5.864 & 2.75 & 12.505 \\
\hline \multicolumn{6}{|c|}{ Menopause age } \\
\hline$\leq 40$ & $4(11.43)$ & $2(20.00)$ & 1 & & \\
\hline $41-49$ & $18(51.43)$ & $4(40.00)$ & 2.250 & 0.3 & 16.854 \\
\hline$\geq 50$ & $13(37.14)$ & $4(40.00)$ & 1.625 & 0.213 & 12.422 \\
\hline \multicolumn{6}{|l|}{ Fertility } \\
\hline No & $8(7.14)$ & $15(10.79)$ & 1 & & \\
\hline Yes & $104(92.86)$ & $124(89.21)$ & 1.573 & 0.641 & 3.855 \\
\hline \multicolumn{6}{|l|}{ Parity } \\
\hline 1 & $18(17.31)$ & $44(35.48)$ & 1 & & \\
\hline 2 & $48(46.15)$ & $60(48.39)$ & 1.956 & 1.004 & 3.812 \\
\hline$\geq 3$ & $38(36.54)$ & $20(16.13)$ & 4.644 & 2.149 & 10.037 \\
\hline \multicolumn{6}{|c|}{ Age at first parity } \\
\hline$<18$ & $9(8.65)$ & $4(3.23)$ & 1 & & \\
\hline $18-30$ & $89(85.58)$ & $110(88.71)$ & 0.360 & 0.107 & 1.206 \\
\hline$\geq 31$ & $6(5.77)$ & $10(8.06)$ & 0.267 & 0.056 & 1.261 \\
\hline \multicolumn{6}{|c|}{ Breast-feeding } \\
\hline No & $18(16.07)$ & $19(13.67)$ & 1 & & \\
\hline Yes & $94(83.93)$ & $120(86.33)$ & 0.827 & 0.411 & 1.663 \\
\hline \multicolumn{6}{|c|}{ Breast-feeding times } \\
\hline$<12$ & $17(17.53)$ & $18(15.00)$ & 1 & & \\
\hline $12-23$ & $61(62.89)$ & $88(73.33)$ & 0.734 & 0.351 & 1.537 \\
\hline$\geq 24$ & $19(19.59)$ & $14(11.67)$ & 1.437 & 0.553 & 3.742 \\
\hline \multicolumn{6}{|l|}{ Abortion } \\
\hline No & $70(62.50)$ & $70(43.88)$ & 1 & & \\
\hline Yes & $42(37.5)$ & $69(56.12)$ & 0.469 & 0.282 & 0.781 \\
\hline \multicolumn{6}{|c|}{ Abortion times } \\
\hline 1 & $16(38.10)$ & $30(43.48)$ & 1 & & \\
\hline 2 & $23(54.76)$ & $26(37.68)$ & 1.659 & 0.726 & 3.793 \\
\hline$\geq 3$ & $3(7.14)$ & $13(18.84)$ & 0.433 & 0.107 & 1.745 \\
\hline \multicolumn{6}{|l|}{ Marriage } \\
\hline No & $7(6.25)$ & $11(7.91)$ & 1 & & \\
\hline Yes & $105(93.75)$ & $128(92.09)$ & 1.289 & 0.483 & 3.442 \\
\hline \multicolumn{6}{|c|}{ BMI $\left(\mathrm{kg} / \mathrm{m}^{2}\right)$} \\
\hline$<25$ & $50(44.64)$ & $88(63.31)$ & 1 & & \\
\hline$\geq 25$ & $62(55.36)$ & $51(36.69)$ & 2.142 & 1.288 & 3.555 \\
\hline
\end{tabular}




\section{Distribution of genotype}

There were 30 cases of the CC genotype, 48 cases of the TC genotype, and 34 cases of the TT genotype in the case group, corresponding to $26.8,42.9$, and $30.4 \%$ of the measured population, respectively. In the control group, there were 25 cases of the CC genotype, 82 cases of the TC genotype, and 32 cases of the TT genotype, which corresponded to $18.0 \%, 59 \%$, and $23.0 \%$ of the measured population, respectively. Two groups had statistical difference $\left(\chi^{2}=\right.$ 6.991, $\mathrm{P}<0.05$, Table 4). The $\mathrm{C}$ and $\mathrm{T}$ allele frequencies of $C Y P 19$ were 48.2 and $51.8 \%$ in the breast cancer group, respectively, and 47.5 and $52.5 \%$ in the control group, respectively. There was no statistical difference between $\mathrm{C}$ and $\mathrm{T}$ allele frequencies $\left(\chi^{2}=0.027, \mathrm{P}>0.05\right.$, Table 4$)$.

\begin{tabular}{|c|c|c|c|c|c|c|c|c|c|}
\hline & \multicolumn{3}{|c|}{ Genotype frequencies } & \multirow[t]{2}{*}{$\chi^{2}$} & \multirow[t]{2}{*}{$P$} & \multicolumn{2}{|c|}{ Allele frequencies } & \multirow[t]{2}{*}{$\chi^{2}$} & \multirow[t]{2}{*}{$P$} \\
\hline & $\mathrm{CC}(\%)$ & TC (\%) & TT (\%) & & & $\mathrm{C}(\%)$ & $\mathrm{T}(\%)$ & & \\
\hline Cases & $30(26.78)$ & $48(42.85)$ & $34(30.35)$ & & & $108(48.21)$ & $116(51.79)$ & & \\
\hline Control & $25(17.99)$ & $82(58.99)$ & $32(23.02)$ & 6.991 & $0.030^{*}$ & $132(47.48)$ & $146(52.52)$ & 0.0027 & 0.471 \\
\hline
\end{tabular}

\section{Genotype and breast cancer}

Compared with the CYP19 gene fragment that carried the CC genotype, the OR for the gene carrying the TC genotype was $0.468(95 \% \mathrm{CI}=0.246-0.892 ; \mathrm{P}<0.05)$, which indicates that the CYP19 gene carrying the TC genotype has a protective factor against Uigur breast cancer. The OR value of the gene carrying the TT genotype was $0.824,(95 \% \mathrm{CI}=0.401-1.692)$ and the TC + TT genotype was $0.570(95 \% \mathrm{CI}=0.311-1.047)$. The $\mathrm{OR}$ value of the $\mathrm{T}$ allele carrier was $0.943(95 \% \mathrm{CI}=0.663-1.342)$, when compared with the $\mathrm{C}$ allele of the $C Y P 19$ gene (Table 5).

Table 5. Relationship between the CYP19 rs10046 genotypes and alleles and breast cancer risk.

\begin{tabular}{lccccl}
\hline CYP19 & Breast cancer (case) & Control (case) & OR & $95 \%$ CI & P \\
\hline Genotype & & & & & \\
CC & 30 & 25 & 1 & & $0.020^{*}$ \\
TC & 48 & 82 & 0.468 & $0.246-0.892$ & 0.598 \\
TT & 34 & 32 & 0.824 & $0.401-1.692$ & 0.068 \\
TC + TT & 82 & 114 & 0.570 & $0.311-1.047$ & \\
Allele & 108 & 132 & 1 & & 0.746 \\
C & 116 & 146 & 0.943 & $0.663-1.342$ & \\
T & & & & &
\end{tabular}

Breast cancer is the most common malignant tumor in women worldwide, and the risk factors related to this disease include family or genetic factors, environmental genetic factors, lifestyle, race, fertility, hormone balance, BMI, and breastfeeding. This study revealed that the age, BMI, parity, fertility, and menopause had a relationship with incidence of breast cancer in Uigur women, which is consistent with previous results (Cheng et al., 2010). Aromatase, which is encoded by CYP19, is a key enzyme for transforming androgen into estrogen. Specifically, it catalyzes the transformation of androstendion and testosterone into estrone and 
estradiol, respectively (Miyoshi et al., 2000; Lee et al., 2003; Song et al., 2006a), and thereby influences the synthesis of estrogen (Figure 4). Estrogen levels have a close relationship with breast cancer.

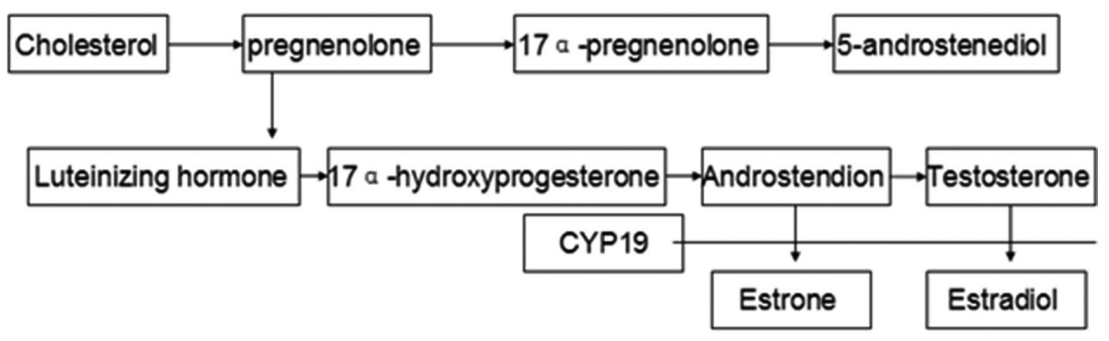

Figure 4. Estrogen synthetase cycle.

Zarrabeitia et al. (2004) showed that the variant contributing to P450 19 gene polymorphism had relationship with estrone synthesis, and revealed that there was relationship between this polymorphism and the susceptibility to breast cancer. Moreover, Rhiem et al. (2003) found that metastasis and the recurrence of breast cancer patients was higher than primary breast cancer significantly $(57.6$ vs $8.9 \%, \mathrm{P}<0.01)$ in CYP19 gene polymorphism. Recently, it was reported that the SNP in the CYP19 gene was related to the susceptibility of Uigur women to breast cancer. Our study selected the rs 10046 site located in 3'-noncoding region, where there existed a C/T SNP. The study of the CYP19 rs10046 genotype distribution in Shanghai (Zhang et al., 2009) and Tianjin (Song et al., 2006b) revealed that the CYP19 rs10046 site polymorphism was related to an individual's susceptibility to developing breast cancer. Moreover, the CYP19 TC genotype and CYP19 T allele also had relationship with the development of breast cancer in Han carriers. This study also observed that the risk of breast cancer increased before menopause. CYP19 with T allele genotype was a strong risk factor, whose risk rate improved the breast cancer significantly. CYP19 with T allele genotype and ER- $\alpha \mathrm{T}$ genotype have a combined effect on breast cancer disease. The study on the Shanghai population indicated that $\mathrm{CC}, \mathrm{CT}$, and TT genotypes, and carriers of the $\mathrm{T}$ allele did not improve the risk of breast cancer significantly. This study revealed that CYP19 rs10046 genotype frequency, in accordance with the H-W balance laws, and the two group genotype distributions were statistically different. Compared with the CC genotype, the TC genotype provided a protective factor of Uigur breast cancer, which conflicted with the results of the study on the domestic Han population. Furthermore, the relationship was not significant between CYP19 TT genotype or T allele frequency and the susceptibility to breast cancer in Uigur women.

\section{ACKNOWLEDGMENTS}

Research supported by the Creative Fund in Xinjiang Medical University (\# XJC201155) Case-control Study on CYP1B1 and CYP19 Gene Polymorphisms and Susceptibility to Breast Cancer in Xinjiang Uigur; the Colleges and Universities Scientific Research (Key) Project in Vygur Autonomous Region of Xinjiang (\# XJEDU2010138) case-control Study on ER $\beta$ and CYP19 Gene Polymorphisms and Susceptibility to Breast Cancer in Xinjiang Uigur; and the Vygur Autonomous Region of Xinjiang Natural Science Foundation (Youth Science Funds) (\#2011211B53). 


\section{REFERENCES}

Cheng F, Zhang Q, Liu WH et al. (2010). 2019 cases of Xinjiang Han, Uigur clinicopathological data analysis. Zhongliu Fangzhi Yanjiu 37: 1312-1314.

Lee KM, Abel J, Ko Y, Harth V, et al. (2003). Genetic polymorphisms of cytochrome P450 19 and 1B1, alcohol use, and breast cancer risk in Korean women. Br. J. Cancer 88: 675-678.

Miyoshi Y, Iwao K, Ikeda N, Egawa C, et al. (2000). Breast cancer risk associated with polymorphism in CYP19 in Japanese women. Int. J. Cancer 89: 325-328.

Rhiem K, Klein A, Munch M, Kreutzfeld R, et al. (2003). Chromosomal region 15q21.1 is a frequent target of allelic imbalance in advanced breast carcinomas. Int. J. Cancer 106: 74-77.

Song CG, Hu Z, Yuan WT, Di GH, et al. (2006a). CYP19A1 gene R264C tendency breast cancer in Shanghai China BRCA1/2 genetic mutation negative. Zhonghua Yixue Yichuanxue Zazhi 23: 181-183.

Song CG, Hu Z, Yuan WT, Di GH, et al. (2006b). Effect of R264C polymorphism in CYP19A1 gene on BRCA1/2negative hereditary breast cancer from Shanghai population of China. Zhonghua Yi Xue Yi Chuan Xue Za Zhi 23: 181-183.

Zarrabeitia MT, Hernández JL, Valero C, Zarrabeitia AL, et al. (2004). A common polymorphism in the 5'-untranslated region of the aromatase gene influences bone mass and fracture risk. Eur. J. Endocrinol. 150: 699-704.

Zhang L, Gu L, Qian B, Hao X, et al. (2009). Association of genetic polymorphisms of ER-alpha and the estradiolsynthesizing enzyme genes CYP17 and CYP19 with breast cancer risk in Chinese women. Breast Cancer Res. Treat. 114: $327-338$. 